\title{
School Zoning: Spatial Justice and Education Policy in Aotearoa New Zealand
}

\section{Georgina Stewart $^{1} \cdot$ Nesta Devine $^{1} \cdot$ Leon Benade $^{1} \cdot$ Daniel Couch $^{1}$}

Published online: 25 May 2021

(c) New Zealand Association for Research in Education 2021

This Special Issue focuses on the nature of spaces where teaching and learning takes place, under the theme of Learning Environments. We are delighted to welcome our Guest Editors for this Special Issue, which is the first to be published by the journal for a number of years. The Guest Editors are Suzanne Trask and Elaine Khoo, whose Guest Editorial directly follows this editorial.

We also take this opportunity to advise our readers of a recent change in the journal editorial team: Leon Benade has stepped down due to workload reasons, and is replaced by Nesta Devine. Daniel Couch joins the team as Book Reviews Editor. It is an opportunity to thank Leon for his substantial contribution to the journal as CoEditor since 2018, and previously as a member of the Editorial Board.

In addition to Learning Environments, school transport, academic streaming, and private/charter schools are other state policies bearing directly on the nexus between space and justice in education. The tension in society between the control of space and the aspiration for social justice, recognizing that spatial arrangements mirror socioeconomic power relations (Lefebvre, 1991; Massey, 1985), is captured in the concept of spatial justice, attributed to postmodernist geographer and urban theorist, Soja $(1989,2010)$. Schools and houses occupy space (real estate) with a permanence that embeds social and educational histories within ongoing attempts to design policy that enhances both excellence and equity in education. Here, we look through the lens of spatial justice to review school zoning, a policy that determines which students can attend which schools, and a political hot potato, given its links to key neoliberal principles such as 'choice' (Thrupp, 2010) and its influence on the price of houses, particularly in the 'speculative' housing market operating today in Auckland and other cities in Aotearoa New Zealand (Rehm \& Yang, 2021).

Historical social egalitarianism in Aotearoa New Zealand impacts on this nexus through, among other things, traditionally high national levels of home ownership, and a high-quality state schooling system, so that (at least, until recently) families in this country felt confident of being able to own their own home and

Georgina Stewart

georgina.stewart@aut.ac.nz

1 Auckland University of Technology, Auckland, New Zealand 
access excellent education for their children, regardless of where they lived. Prior to the neoliberal reforms the national norm was attending local schools, expressed in policy as 'area zoning' and in place since at least 1950 on the grounds of being 'fairer' than if schools were allowed to make their own selections (see McCulloch, 1991, p. 158). Then-Minister Algie conceded there was tolerance in the system for 'personal factors' (i.e. wealth). Enrolment zones operated only for the most prestigious schools, e.g. the Grammar Zone in Auckland, which openly targeted the richest families on the isthmus based on 'old money' and residues of imperialist traditions (McCulloch, 1988). The old Grammar Zone traced the wealthiest inner Auckland suburbs, giving it a bizarre shape on the map. In addition to an increasingly noticeable divide along socio-economic lines, factors around school enrolment following 1950 had seen existing ethnic segregation become more pronounced (Waslander \& Thrupp, 1995).

By the 1970s there was growing discontent with school zoning, based on a general undermining of egalitarian traditions in this country and an economistic 'concern to open up schools to the pressures and opportunities of the market place' (McCulloch, 1991, p. 159). Those on the political Left saw zoning as entrenching inequality, while those on the Right increasingly blamed local or residential zoning for the "failure of schools to be accountable to parents or to achieve competitive standards' (p. 159). The neoliberal reforms of education by the fourth Labour government included dezoning admissions as part of Tomorrow's Schools, but the right of students to attend their local school was protected. The National government (1990-1999) went further towards marketising school enrolment policy, making overcrowding the only grounds on which schools could apply for an enrolment scheme (Thrupp, 2010).

The idea of dezoning was for 'the community' to take more part in the governance of schools, and that parents should make choices about the schools their children attended, so that 'better' schools would grow bigger and less desirable schools would implode, and preferably be taken over by 'better' schools, which would then institute their practices, raise the level of education, and improve standards overall. The eventual aim was to provide each child with a 'voucher' for education that could be cashed in at a school of the parents' choice. The stimulus for the dezoning policy, as with so much of the 1980s reform programme, comes from the US. In an attempt to bypass racial desegregation, James Buchanan at the Virginia Polytech developed a scheme by which schools would specialise in various subjects or skills, and parents, in an analogy with the workings of the market, would exercise 'choice' to enable them to bypass the local (desegregated) school in favour of a specialist (or 'charter') school, which would be, in effect, still segregated (Devine, 2004; McLean, 2017).

It is doubtful if the New Zealand architects of this scheme understood the racial significance of their plans: dog whistles that sounded loudly for parents in segregationist communities in the US may have been inaudible to the economists who adopted the mantras of 'choice' and 'competition' without understanding the implications. But although some bewailed the middle-class abandonment of community schools, so that the core populations left behind were definably Māori and Pacific, and impoverished, it is obvious that the system was working exactly as it was supposed to. 
Dezoning created a flow of students away from schools in lower socioeconomic status (SES) neighbourhoods towards higher SES schools, but with access to the highest SES schools controlled by their 'overcrowding status' (Thrupp, 2010, p. 49). A decade of market policies that pitted choice against zoning created or exacerbated the segregation of school populations, in response to which, from 2000, when Labour returned to power, zones have been gradually reinstated, as national enrolment policies have 'moved back from the market' (Thrupp, 2007, p. 1393). The effect of reintroducing zones on Auckland house prices in the early 2000s was rapid and measurable, especially in parts of Epsom and Mount Eden (Rehm \& Filippova, 2008). Today, the Grammar zones continue to command a large premium in the speculative housing market; it is evident that social inequality and power relations cannot be controlled by school enrolment policies, confounding simplistic assumptions e.g. choice good, zoning bad (Thomson, 2010). Wealthy families inevitably find ways to take advantage of education policies, including enrolment policies (Thrupp, 2010).

Now in its second term, the Labour-led government recently announced significant increases in school zoning in Auckland, with plans to implement 135 new or amended enrolment zones over 3 years (2021-2023). Aimed at managing growing student numbers and existing school stock more efficiently, the plan aims to save 'tens of millions of dollars' (Gerritsen, 2020).

Rezoning to optimise the physical capacities of the long-term investment the taxpayer has made in school buildings and amenities makes admirable sense: arguably, it would be remiss of the government to allow some existing buildings to go unused, and others to be overused. Likewise, there is suspicion about whether or not super-sized schools are good for students. A convincing argument is made that staff 'knowing' the students, and students 'knowing' the staff, makes for a more amiable school environment, and reduces the amount of distress and bullying.

But these plans to boost zoning regulations have called out two strong responses: one from families whose younger children cannot follow in the footsteps of their older siblings, and the other from Auckland school principals, who would like to see zoning abolished. In most cases schools will be able to accommodate younger siblings, but there may well be situations where schools under pressure for space have to institute a strict zoning policy, so that younger siblings miss out, with consequent expenses in time and money: new uniforms, more driving to and from schools, more attendance at parent-teacher meetings, more strain for parents in getting to know new teachers and different environments.

Sought-after schools must cope with all the possibilities of fraud, for instance by demanding to see recent bills, to try to make sure that student addresses are genuine. Students who 'live' with grandma, or at the family business address, are a constant headache for school enrolment schemes, and one reason why the principal of Auckland Grammar School would like to see the end of zoning. But precisely because this school is so successful, it would then attract even more students, and draw even more away from local schools, compounding Auckland's traffic problems in the process.

Zoning is therefore not only an attempt to spend public money wisely, but also to ameliorate some of the spatial injustices which embed outrageous inequalities 
into our education system. Parents should be welcomed back into neighbourhood schools; their drive and care for their children's education should be utilised for everyone's benefit. The idea of 'choice' is a difficult one to put back in the bag, but perhaps parents can be persuaded to 'choose' to spend more time and attention on the neighbourhood school, perhaps instead of hours a day driving, thus helping to create the school of their dreams.

\section{References}

Devine, N. (2004). Education and public choice: A critical account of the invisible hand in education. Praeger.

Gerritsen, J. (2020). Big increase in enrolment zones for Auckland schools. https:/www.rnz.co.nz/news/ national/428745/big-increase-in-enrolment-zones-for-auckland-schools

Lefebvre, H. (1991). The production of space (D. Nicholson-Smith, Trans.). Blackwell.

Massey, D. (1985). New directions in space. In D. Gregory \& J. Urry (Eds.), Social relations and spatial structures (pp. 9-19). Macmillan.

McCulloch, G. (1988). Imperial and colonial designs: The case of Auckland Grammar School. History of Education, 17(4), 257-267. https://doi.org/10.1080/0046760880170401

McCulloch, G. (1991). School zoning, equity and freedom: The case of New Zealand. Journal of Education Policy, 6(2), 155-168. https://doi.org/10.1080/0268093910060204

McLean, N. (2017). Democracy in chains: The deep history of the radical right's stealth plan for America. Viking.

Rehm, M., \& Filippova, O. (2008). The impact of geographically defined school zones on house prices in New Zealand. International Journal of Housing Markets and Analysis, 1(4), 313-336. https://doi. org/10.1108/17538270810908623

Rehm, M., \& Yang, Y. (2021). Betting on capital gains: Housing speculation in Auckland, New Zealand. International Journal of Housing Markets and Analysis, 14(1), 72-96. https://doi.org/10.1108/ IJHMA-02-2020-0010

Soja, E. (1989). Postmodern geographies: The reassertion of space in critical social theory. Verso.

Soja, E. (2010). Seeking spatial justice. University of Minnesota Press.

Thomson, K. S. (2010). Externalities and school enrollment policy: A supply-side analysis of school choice in New Zealand. Journal of School Choice, 4(4), 418-449.

Thrupp, M. (2007). School admissions and the segregation of school intakes in New Zealand Cities. Urban Studies, 44(7), 1393-1404.

Thrupp, M. (2010). Choice and zoning. In M. Thrupp \& R. Irwin (Eds.), Another decade of New Zealand education policy: Where to now? (pp. 47-55). WMIER.

Waslander, S., \& Thrupp, M. (1995). Choice, competition and segregation: An empirical analysis of a New Zealand secondary school market, 1990-93. Journal of Education Policy, 10(1), 1-26. https:// doi.org/10.1080/0268093950100101

Publisher's Note Springer Nature remains neutral with regard to jurisdictional claims in published maps and institutional affiliations. 